\title{
Correction to: Cemiplimab: A Review in Advanced Cutaneous Squamous Cell Carcinoma
}

\author{
Arnold Lee $^{1} \cdot$ Sean Duggan ${ }^{1} \cdot$ Emma D. Deeks $^{1}$
}

Published online: 30 May 2020

C) Springer Nature Switzerland AG 2020

\section{Correction to: Drugs (2020) 80:813-819}

https://doi.org/10.1007/s40265-020-01302-2

Page 815, table 1, Efficacy of cemiplimab in adults with locally advanced or metastatic cutaneous squamous cell cancer in EMPOWER-CSCC 1: The title for the dosage on line 3 , which previously read:

"Cemipliab $3 \mathrm{mg} / \mathrm{kg}$ once every 2 weeks $\mathrm{b}$ "

should read:

"Cemiplimab 3 mg/kg once every 2 weeks $\mathrm{b}$ "

The original article can be found online at https://doi.org/10.1007/ s40265-020-01302-2.

Arnold Lee

demail@springer.com

1 Springer Nature, Private Bag 65901, Mairangi Bay, Auckland 0754, New Zealand 